\title{
Faktor Produksi Usaha Ternak Itik Petelur Semi Intensif Di Kabupaten Jember
}

\section{Production Factor Affecting Layer Duck Bussiness of Semi-Intensive Poultry Farm in Jember Regency}

\author{
${ }^{\# 1}$ Hariadi Subagja, ${ }^{\# 2}$ Budi Prasetyo, Heny Nurjanah \\ ${ }^{\#}$ Jurusan Peternakan Politeknik Negeri Jember \\ Jalan Mastrip Kotak Pos 164 Jember \\ ${ }^{1}$ hariadisubagja@gmail.com \\ ${ }^{2}$ bprasetyo91@gmail. com
}

\begin{abstract}
The Research Was Aimed To Know Factors That Influence And Dominant To Egg Layer Duck Bussiness Of Semi-Intensive Poultry Farm In Jember. The Method Used Is Survey Method With 30 Respondents SemiIntensive Duck Breeders. The Result Of Data Processing Using Multiple Linier Regression Can Be Acquired Aquation:

$$
Y=6576,602-15.376 X_{1}+0,001 X_{2}+0,061 X_{3}+0,013 X_{4}-0,022 X_{5}-192,147 X_{6}-410,626 X_{7}+U
$$

From The Equation Means That For Every Unit Of Egg Production Will Be Affected By $X_{1}$ (Age Of Ducks) Of $15,376, X_{2}$ (Feed) Of 0,001, $X_{3}$ (Medication) Of 0,061, $X_{4}$ (Employee) Of -0,013, $X_{5}$ (Fuel) Of -0,022, $X_{6}$ (Density Of Cage) Of -192,147, And $X_{7}$ (Long Of Free-Range) Of -410,626. Can Be Concluded Employee Factor Have A Major Influence On The Production Of Duck Eggs. Result Of Calculation Of The Coefficient Of Determination Is 76,5\% And The Remaining 23,5\% Is Explained By Other Variables Not Included In This Research.
\end{abstract}

Keywords : Ducks, Semi-Intensive, Production Factors, Multiple Linier Regression Analysis

\section{PENDAhuluan}

Masalah utama yang dihadapi oleh negara berkembang seperti Indonesia adalah di bidang ekonominya yang masih sangat lemah. Realisasi pertumbuhan ekonomi Indonesia tahun 2013 hanya mencapai $5,8 \%$ yaitu lebih rendah bila dibandingkan dengan target APBNP-nya sebesar 6,3\% (Anonimus, 2014a). Indonesia perlu melakukan pembangunan ekonomi agar taraf hidup penduduk menjadi lebih baik dengan harapan terjadi peningkatan kesejahteraan. Sebagian besar penduduk Indonesia memiliki sumber mata pencaharian dibidang pertanian yaitu sebagai petani dan peternak. Oleh karena itu, sektor pertanian merupakan salah satu sektor yang mempunyai kontribusi besar terhadap tingkat perekonomian Indonesia.

Peternakan merupakan salah satu subsektor pertanian yang sangat potensial untuk dikembangkan karena subsektor ini memberikan sumbangan cukup besar untuk sektor pertanian Indonesia. Itik petelur merupakan ternak unggas air yang dipelihara khusus untuk menghasilkan telur. Populasi itik di Jawa Timur pada tahun 2014 mencapai 4,9 juta ekor dan jumlah produksi telur itik sebanyak 32 juta kg (Anonimus, 2014b). Usaha itik petelur mempunyai peluang cukup besar untuk terus dikembangkan karena permintaan telur semakin tinggi seiring meningkatnya kesadaran masyarakat akan gizi guna kelangsungan hidup 
Hariadi Subagja, Budi Prasetyo, Heny Nurjanah. Faktor Produksi Usaha Ternak Itik Petelur Semi Intensif

Di Kabupaten Jember.

yang lebih baik. Konsumsi telur itik masyarakat Jawa Timur pada tahun 2014 adalah 1,51 per kapita dan total kebutuhan telur itik sebanyak 62,06 juta kg (Anonimus, 2014b). Kebutuhan telur itik masyarakat belum terpenuhi oleh total produksi yang tersedia saat ini.

Kabupaten Jember merupakan daerah dengan kondisi lingkungan yang cukup baik untuk pengembangan itik petelur. Daerah ini mempunyai curah hujan >2500 mm/tahun, terletak pada ketinggian dibawah 100 meter dpl (Kabupaten Jember, 2015) dan iklim tropis dengan suhu lingkungan $23^{\circ}-32^{\circ} \mathrm{C} \quad$ (Wikipedia, 2015). Kabupaten Jember mempunyai populasi ternak itik sebanyak180 ribu ekor dan jumlah produksi telur adalah 1,17 juta kg pada tahun 2014 (Anonimusr, 2015c).

Peternak di daerah Kabupaten Jember menggunakan sistem pemeliharaan semi intensif yaitu dengan cara kombinasi antara mengandangkan dan menggembalakan itik. Menurut Bharoto (2001) dan Martawijaya dkk, (2004) dalam Budiraharjo (2008) itik mampu memproduksi telur 203-232 butir/ekor/tahun dengan pemeliharaan sistem semi intensif.

Menjalankan usaha peternakan yang berkaitan dengan produksi, peternak dihadapkan dengan beberapa masalah atau resiko usaha seperti resiko gagal produksi disebabkan oleh faktorfaktor produksi dan harga jual telur dipasar yang tidak pasti. Peternak sering kali mengabaikan dan tidak memahami pengetahuan tentang faktor-faktor produksi usaha ternak sehingga hasil usaha kurang maksimal terutama. Menurut Yunus (2009) dalam menjalankan suatu usaha produksi ternak, pelaku usaha/ peternak harus paham mengenai faktorfaktor yang berkaitan dengan usaha produksi yaitu breeding (pembibitan), feeding (makanan ternak/pakan), dan manajemen (pengelolaan) produksi sehingga usaha mempunyai tingkat keberhasilan yang tinggi. Aziz (2009) dalam David (2013) menambahkan bahwa faktor yang mempengaruhi usaha ternak adalah faktor produksi yang dibagi menjadi faktor produksi tetap (lahan, kandang dan peralatan) dan faktor produksi variabel (bibit atau DOD, pakan, obat-obatan, vaksin, vitamin, sekam, air, listrik, bahan bakar untuk pemanas dan tenaga kerja).

Melihat sedikitnya populasi itik petelur dan potensi lingkungan Kabupaten Jember serta permasalahan yang sering dihadapi oleh peternak terkait produksi usaha, maka perlu dilakukan studi tentang faktor-faktor produksi apa saja dan bagaimana peternak memahami faktor-faktor produksi yang diterapkan dalam pemeliharaan itik petelur. Sehingga dengan dilakukan studi tersebut diharapkan mampu memberikan analisis yang akurat terhadap faktor-faktor produksi pemeliharaan itik secara semi intensif dan memberikan dampak yang baik terhadap kualitas dan kuantitas telur yang dihasilkan.

\section{METODE PENELITIAN}

Kabupaten Jember dipilih sebagai lokasi penelitian dengan pertimbangan bahwa wilayah ini mempunyai potensi lingkungan yang memungkinkan untuk pengembangan usaha ternak itik petelur. Lokasi penelitian pada tingkat kecamatan dilakukan dengan memilih 5 kecamatan secara purposive dari seluruh kecamatan yang ada di Kabupaten Jember. Selanjutnya pengambilan responden dilakukan dengan metode purposive sampling, yaitu dengan mengambil seluruh peternak itik yang menerapkan sistem pemeliharaan semi intensif yang ada di lima kecamatan terpilih. Penelitian dilakukan dengan metode survai, yaitu penelitian yang mengambil sampel dari satu populasi. Data primer yang meliputi identitas responden, faktor-faktor yang diduga mempengaruhi produksi telur ada usaha ternak itik diperoleh dari observasi dan wawancara terhadap responden dengan bantuan kuesioner. Data sekunder berkaitan dengan usaha ternak itik diperoleh dari observasi dan catatan pada instansi terkait. Untuk mengetahui faktor-faktor yang mempengaruhi produksi usaha ternak itik dianalisis menggunakan analisis regresi linier berganda. Hasil pendugaan akan diuji asumsi klasik untuk memenuhi kriteria ekonometrika yang meliputi meliputi uji normalitas, uji multikolinearitas, dan uji heterokedastisitas . Hasil Pendugaan juga akan diuji secara statistik dengan mengunakan uji F, uji t, koefisien determinasi $\left(\mathrm{R}^{2}\right)$ dan adjusted $R$ square.

\section{III.HASIL DAN PEMBAHASAN} Analisis Regresi Linier Berganda

Analisis regresi linier berganda digunakan untuk mengetahui pengaruh variabel Umur itik $\left(\mathrm{X}_{1}\right)$, Konsumsi Pakan $\left(\mathrm{X}_{2}\right)$, OVAC (Obat-obatan, 
Vitamin dan Vaksin) $\left(\mathrm{X}_{3}\right)$, Tenaga Kerja $\left(\mathrm{X}_{4}\right)$, Bahan Bakar $\left(\mathrm{X}_{5}\right)$, Kepadatan Kandang $\left(\mathrm{X}_{6}\right)$ dan Lama Penggembalaan $\left(\mathrm{X}_{7}\right)$ terhadap Produksi Telur Itik (Y). Berdasarkan analisis regresi linier berganda maka dapat dihasilkan persamaan regresi sebagai berikut :

$$
\begin{aligned}
& Y=6576,602-15.376 X_{1}+0,001 X_{2}+0,061 X_{3}+ \\
& 0,013 X_{4}-0,022 X_{5}-192,147 X_{6}-410,626 X_{7}+u
\end{aligned}
$$

Konstanta persamaan regresi (a) bernilai positif. Artinya, jika variabel-variabel bebas sama dengan nol, maka produksi telur itik persatuan ternak adalah sebesar 6576,602 butir per bulan.

\section{Umur Itik}

Nilai t-hitung variabel umur itik adalah sebesar $-1,102$, sedangkan nilai t-tabel ${ }_{(5 \%)}$ adalah sebesar 1,717 (t-hitung $\left.<\mathrm{t}_{\text {-tabel5\% }}\right) . \quad$ Hal ini menunjukkan bahwa variabel umur itik secara parsial tidak berpengaruh nyata terhadap variabel produksi telur itik. Semakin tinggi umur ternak yang dipelihara maka produksi telurnya semakin turun. Setelah melewati masa produksi pertama selama 12 bulan, itik akan mengalami masa rontok bulu (1 bulan), kemudian akan kembali memasuki masa produksi yang kedua namun pada masa produksi setelah rontok bulu ini, produksi telur itik tidak setinggi pada awal masa produksi (Trubus, 2010).

\section{Konsumsi Pakan}

Nilai t-hitung variabel pakan adalah sebesar 2,326, sedangkan nilai $\mathrm{t}-\operatorname{tabel}_{(5 \%)}$ adalah sebesar 1,1717 (t-hitung $>\mathrm{t}^{-}$-tabel5\%). Hal ini menunjukkan bahwa variabel konsumsi pakan secara parsial berpengaruh nyata terhadap variabel produksi telur itik.

Kandungan nutrisi dalam pakan itik merupakan salah satu faktor produksi yang sangat berpengaruh terhadap produksi telur itik. Protein dan energi yang terkandung dalam pakan kemudian dikonsumsi itik dan digunakan untuk memenuhi kebutuhan hidup pokok dan untuk memproduksi telur. Menurut Septyana (2008) ransum dengan kualitas baik (keseimbangan energi dan protein) akan menghasilkan produksi telur tinggi dan dapat dipertahankan sampai akhir masa produksi. Brand, dkk (2003) dalam Septyana (2008) menambahkan bahwa pembentukan telur itik dipengaruhi oleh besarnya konsumsi energi dan protein ransum yang diberikan. Ransum dengan kandungan energi dan protein dalam jumlah terbatas menyebabkan itik berkompensasi mengurangi ukuran dan jumlah telur yang dihasilkan atau memperpanjang interval bertelur. Kebutuhan protein dan energi itik petelur berturut-turut adalah 17-19\% dan $2700 \mathrm{kkal} / \mathrm{kg}$ (Sinurat, 2000 dalam Ketaren, 2002).

Jumlah pemberian pakan itik juga berpengaruh terhadap produksi telur itik. Pasalnya itik tidak mampu menghasilkan telur jika jumlah pakan yang dikonsumsi tidak memenuhi kebutuhan produksinya. Jumlah pakan yang diberikan oleh peternak itik semi intensif di Kabupaten Jember rata-rata adalah 157 gram/ekor/hari. Payne (1993) dalam Susanto (2004) merekomendasikan kebutuhan ransum untuk konsumsi normal itik masa produksi adalah 170-227 gram per ekor per hari.

\section{OVAC (Obat-obatan, Vitamin dan Vaksin)}

Nilai t-hitung variabel OVAC adalah sebesar 0,974 , sedangkan nilai $\mathrm{t}-\operatorname{tabel}_{(5 \%)}$ adalah sebesar 1,717 ( $\mathrm{t}_{\text {-hitung }}<\mathrm{t}$-tabel5\%). Hal ini menunjukkan bahwa variabel OVAC secara parsial tidak berpengaruh nyata terhadap variabel produksi telur itik.

Itik lokal secara genetik mempunyai sistem kekebalan tubuh yang lebih baik dibandingkan dengan jenis itik lainnya. Hal ini dipengaruhi oleh kebisaan itik lokal yang digembalakan sehingga secara alami tubuh lebih leluasa bergerak dan lebih tahan terhadap serangan penyakit. Sistem pemeliharaan dengan cara menggembalakan itik di areal tertentu mampu merangsang daya tahan tubuh itik sehingga itik lebih kebal terhadap serangan penyakit dibandingan dengan itik yang tidak pernah digembalakan. Menurut Iskandar (2010) pada umumnya walau dengan kondisi pemeliharaan sederhana, unggas-unggas lokal seperti ayam kampung dan itik lokal mempunyai tingkat kekebalan tubuh lebih baik dibandingkan dengan unggas impor. Suharno (2009) menyatakan bahwa itik lokal memiliki kekebalan maternal dan respon kekebalan primer yang lebih tinggi dibandingkan dengan itik impor sehingga secara alami itik lokal mampu mempertahankan diri dari serangan virus dan bibit penyakit lainnya, dimana kemampuan alami itik dalam mempertahankan diri ini dikendalikan oleh gen antiviral.

Selain dipengaruhi oleh gen antiviral yang secara genetik dimiliki oleh itik lokal, kemampuan mempertahankan diri terhadap penyakit dan 
Hariadi Subagja, Budi Prasetyo, Heny Nurjanah. Faktor Produksi Usaha Ternak Itik Petelur Semi Intensif Di Kabupaten Jember.

kematian yang tinggi juga disebabkan oleh tingginya jumlah sel darah putih pada itik lokal sehingga itik tidak memerlukan vitamin maupun obat-obatan sebagai penghilang stress dan penyembuh sakit. Menurut Dewantari (2002) dalam Lestari, dkk (2013) itik lokal mempunyai aya tahan tubuh lebih tinggi dibandingkan dengan unggas lainnya karena memiliki perbedaan faktor genetik pada fisiologi tubuh, salah satunya adalah leukosit. Penggunaan OVAC yang tidak rutin dan tidak sesuai syarat penggunaannya menyebabkan biaya penggunaan OVAC pada penelitian ini tidak berpengaruh nyata terhadap produksi telur itik. Pemberian obat-obatan, vaksin dan vitamin dapat meningkatkan produksi telur itik namun jika penggunaannya tidak sesuai dengan aturan penggunaan justru akan menurunkan dan tidak berpengaruh terhadap produksi telur. Menurut Yunus (2009) peternak mandiri pada umumnya hanya mengandalkan pengalaman dan metode coba-coba dalam hal pemberian obat-obatan (antibiotik) dan faktor yang menyebabkan terjadinya kegagalan pengobatan adalah diagnosis salah, pemilihan obat salah, dosis dan aplikasi tidak benar, bakteri tidak sensitif karena resistan, kualitas pakan dan manajemen penggunaan pengobatan kurang baik.

\section{Tenaga Kerja}

Nilai t-hitung variabel tenaga kerja adalah sebesar 4,458, sedangkan nilai t-tabel $l_{(1 \%)}$ adalah sebesar 2,508 ( $\mathrm{t}_{\text {-hitung }}>\mathrm{t}$-tabel1\%). Hal ini menunjukkan bahwa variabel tenaga kerja secara parsial sangat berpengaruh nyata terhadap variabel produksi telur itik.

Penggunaan biaya tenaga kerja biasanya dikaitkan dengan kemampuan, keterampilan dam pengalaman tenaga kerja dalam merawat dan mengurus ternak yang dipelihara. Semakin tinggi kemampuan dan keterampilan yang dimiliki tenaga kerja maka semakin tinggi upah yang didapatkan. Khoiriyah (2009) menyatakan bahwa upah sebenarnya merupakan imbalan jasa atas prestasi kerja yang telah dilakukan, semakin tinggi prestasi kerja yang dicapai seharusnya semakin besar pula upah yang akan diterima oleh tenaga kerja, sedangkan prestasi kerja dapat ditunjukkan dengan produktivitas kerja.

\section{Bahan Bakar dan Listrik}

Nilai t-hitung variabel bahan bakar adalah sebesar 1,537, sedangkan nilai t-tabel $\mathrm{l}_{(5 \%)}$ adalah sebesar

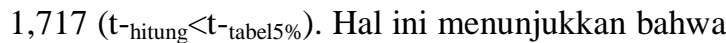
variabel bakan bakar secara parsial tidak berpengaruh nyata terhadap variabel produksi telur itik.

Peternak yang menggunakan penerangan untuk itiknya hanya $53 \%$ dan $47 \%$ lainnya memilih untuk tidak menggunakan penerangan saat malam hari karena dirasa itik tidak membutuhkan cahaya pada saat malam hari. Itik yang tidak mendapatkan cukup cahaya menyebabkan berkurangnya kemampuan memproduksi telur sehingga jumlah telur yang dihasilkan berkurang. Rata-rata itik digembalakan atau digembalakan selama 7 jam perhari dengan cahaya yang didapatkan berasal dari cahaya matahari. Menurut Anonimus (2014c) agar itik petelur berproduksi maksimal maka kebutuhan cahaya yaitu 16 jam/perhari (16 jam terang dan 8 jam gelap) harus terpenuhi. Kebutuhan cahaya itik petelur semi intensif di Kabupaten Jember belum terpenuhi sehingga hal ini diduga menyebabkan tidak berpengaruhnya biaya listrik/bahan bakar sebagai sumber cahaya terhadap produksi telur

\section{Kepadatan Kandang}

Nilai t-hitung variabel kepadatan kandang adalah sebesar $-2,376$, sedangkan nilai $\mathrm{t}$ - $\operatorname{tabel}_{(5 \%)}$ adalah sebesar 1,717 (t-hitung $>\mathrm{t}_{\text {-tabel5\%). Hal ini }}$ menunjukkan bahwa variabel kepadatan kandang secara parsial berpengaruh nyata terhadap variabel produksi telur itik.

Kepadatan populasi dalam kandang dapat mempengaruhi pertumbuhan dan produksi telur itik. Keadaan kandang yang terlalu sempit dapat mengakibatkan peningkatan akumulasi zat karbon dioksida serta penurunan kadar oksigen dalam kandang yang dapat menyebabkan pertumbuhan lambat, produksi telur rendah dan meningkatnya angka kematian karena itik rentan terhadap penyakit (Dadang, dkk., Tanpa Tahun). Hapsari (2013) menambahkan semakin padat kandang itik, maka akan cenderung meningkatkan konsumsi air minum saja karena itik merasa sesak (panas) akibat amoniak dalam kandang saat malam hari sehingga menyebabkan terganggunnya metabolisme tubuh dan menurunkan produksi telur. 


\section{Lama Penggembalaan}

Nilai t-hitung variabel lama penggembalaan adalah sebesar $-2,766$, sedangkan nilai $\mathrm{t}-\mathrm{tabel}_{(5 \%)}$ adalah sebesar 2,508 ( $_{\text {-hitung }}>\mathrm{t}$ tabel1\%). Hal ini menunjukkan bahwa variabel lama penggembalaan secara parsial sangat berpengaruh nyata terhadap variabel produksi telur itik.

Lama penggembalaan dapat memicu tingginya tingkat morbiditas (persentase itik sakit) dan mortalitas (persentase itik mati) karena lahan yang digunakan untuk gembala mempunyai kandungan limbah atau racun sehingga mengganggu kesehatan itik. Itik yang sakit produksi telurnya terus menurun sehingga produksi telur setiap periode juga menurun, akibatnya pendapatan peternak juga semakin rendah karena harus mengobati tersebarnya penyakit pada itik-itik lainnya. Wakhid (2010) menyatakan bahwa harus diperhatikan bahwa sawah atau sungai tempat mengangon itik harus terbebas dari limbah berbahaya dan tidak mengandung pertisida yang membahayakan itik. Fadilah (2004) dalam Hapsari (2013) menyatakan bahwa mortalitas dan kesehatan itik berpengaruh terhadap produksi telurnya karena adanya gangguan metabolisme sehingga tubuh itik tidak mampu memproduksi telur seperti biasa. Akibat berkurangnya produksi telur harian itik yang terus menurun akibat gangguan kesehatan berdampak pada produksi telur setiap periode.

\section{Uji Keterandalan Model (Uji F)}

Nilai F-hitung pada hasil analisis adalah 10,244 dan nilai $\mathrm{F}_{\text {tabel }(5 \%)}$ adalah $2,46, \mathrm{~F}_{\text {tabel }(1 \%)}$ adalah 3,59, maka $\mathrm{F}_{\text {-hitung }}>\mathrm{F}_{\text {tabel }(1 \%)}(10,244>3,59)$. Hal ini menunjukkan bahwa di antara variabelvariabel independen (umur itik, konsumsi pakan, OVAC (obat-obatan, vitamin dan vaksin), tenaga kerja, bahan bakar, kepadatan kandang dan lama penggembalaan) sangat berpengaruh nyata secara bersama terhadap variabel produksi telur itik.

\section{Koefisien Determinasi $\left(\mathbf{R}^{2}\right)$}

Nilai koefisien determinasi pada
penelitian ini terhadap variabel-variabel berpengaruh sebesar 0,765 , artinya variabel independen (umur itik, konsumsi pakan, OVAC (obat-obatan, vitamin dan vaksin), tenaga kerja, bahan bakar, kepadatan kandang dan lama penggembalaan) berpengaruh terhadap variabel dependen (produksi telur itik) sebesar 76,5\% sedangkan sisanya $23,5 \%$ dipengaruhi oleh faktor diluar faktor-faktor (variabel) yang diteliti.

\section{Adjusted R Square}

Nilai adjusted $R$ square tidak dipengaruhi oleh bertambahnya jumlah variabel independen. Nilai adjusted $R$ square pada penelitian ini adalah 0,691 , artinya variabel dependen dijelaskan sebanyak $69,1 \%$ oleh variabel bebas yang signifikan berpengaruh pada penelitian ini.

\section{KESIMPULAN DAN SARAN}

\section{Kesimpulan}

a. Berdasarkan analisis regresi linier berganda dan hasil uji parsial, faktor produksi yang berpengaruh terhadap produksi itik petelur semi intensif adalah adalah konsumsi pakan $\left(\mathrm{X}_{2}\right)$ disebabkan kebutuhan nutrisi seperti energi dan protein itik sudah terpenuhi; tenaga kerja $\left(\mathrm{X}_{4}\right)$ disebabkan pengalaman dan keterampilan tenaga kerja saat memelihara itik; kepadatan kandang $\left(\mathrm{X}_{6}\right)$ karena semakin banyak jumlah itik dalam kandang maka kenyaman itik terganggu dan lama penggembalaan $\left(\mathrm{X}_{2}\right)$ karena potensi pakan di lahan penggembalaan yang sedikit serta tingginya tingkat mordibitas itik.

b. Faktor produksi yang tidak berpengaruh terhadap produksi telur itik semi intensif adalah umur itik, OVAC (obat-obatan, vitamin dan vaksin) dan bahan bakar.

c. Faktor produksi yang dominan berpengaruh terhadap produksi telur itik dengan sistem pemeliharaan semi intensif di Kabupaten Jember adalah tenaga kerja.

\section{Saran}

a. Guna meningkatkan produksi telur itik yang dipelihara secara semi intensif di Kabupaten Jember disarankan agar peternak lebih memperhatikan faktor -faktor produksi seperti faktor konsumsi pakan agar itik memperoleh nutrisi yang cukup untuk berproduksi; faktor kepadatan kandang agar kenyaman itik dapat terjamin; serta faktor umur itik agar menggunakan itik dengan umur produktif.

b. Agar model regresi lebih sempurna, disarankan agar menggunakan variabel bebas atau independen yang lebih banyak. 
Hariadi Subagja, Budi Prasetyo, Heny Nurjanah. Faktor Produksi Usaha Ternak Itik Petelur Semi Intensif Di Kabupaten Jember.

\section{DAFTAR PUSTAKA}

[1]_ 2014c. Pencahayaan Harus di Program dengan Baik. http://info.medi on.co.id.

[2] Dadang. A.Y., E. Sudjarwo., Achmanu. Tanpa Tahun. The Influences of Cage Density On Performance of Hybrid And Mojosari Duck In Finisher Period. Jurnal. University of Brawijaya.

[3] Hapsari. H. W. 2013. Analisis Efisiensi Faktor yang Mempengaruhi Produksi Ayam Ras Pedaging Pola KEmitraan dan Mandiri di Kecamatan Gunung Sindur Kabupaten Bogor. Skripsi. Institut Pertanian Bogor.

[4] Iskandar. S. 2010. Usaha Tani Ayam Kampung. Balai Penelitian Ternak Ciawi. Bogor,

[5] Ketaren. P.P. 2002. Kebutuhan Gizi Itik Petelur dan Itik Pedaging. Wartazoa. Vol 12. No 2.

[6] Khoiriyah. L. 2009. Pengaruh Upah dan Lingkunan Kerja Terhadap Kinerja Karyawan Pada CV. Aji Bali Jayawijaya Surakarta. Skripsi. Universitas Muhammadiyah Surakarta.

[7] Lestari.S.H.A, Ismoyowati, M. Indradji. 2013. Kajian Jumlah Leukosit dan Diferensial Leukosit Pada Berbagai Jenis Itik Betina yang Pakannya di Suplementasi Probiotik. Jurnal Ilmiah Peternakan. Vol 1. No 2 (699-709).

[8] Septyana. M. 2008. Performans Itik Petelur Lokal Dengan Pemberian Tepung Daun Katuk (Sauropus androgynus (L.) Merr:) Dalam Ransumnnya. Skripsi. Institut Pertanian Bogor.

[9] Suharno. B. 2009. Beternak Itik Secara Intensif. Penebar Swadaya. Jakarta.

[10] Susanto. S. R. 2004. Pengaruh Perbedaan Tingkat Protein Dalam Ransum Dengan Penambahan Probiotik Terhadap Produktivitas Itik Indian Runner. Skripsi. Universitas Sebelas Maret.

[11] Wakid. 2010. Buku Pintar Beternak dan Bisnis Itik. Agromedia Pustaka. Jakarta

[12] Yunus. R. 2009. Analisis Efisiensi Produksi Usaha Peternakan Ayam Ras Pedaging Pola Kemitraan dan Mandiri Di Kota Palu Provinsi Sulawesi Tengah. Tesis. Universitas Diponegoro Semarang. 